\title{
EFFECT OF CADMIUM ON GROWTH, PHOTOSYNTHETIC PIGMENTS, IRON AND CADMIUM ACCUMULATION OF FABA BEAN (VICIA FABA CV. AŠTAR)
}

\author{
BEÁTA PIRŠELOVÁ ${ }^{1 *}$, ROMAN KUNA ${ }^{1}$, PETER LUKÁČ ${ }^{2}$, MICHAELA HAVRLENTOVÁ ${ }^{3}$
}

\author{
${ }^{1}$ Constantine the Philosopher University in Nitra, Slovak Republic \\ ${ }^{2}$ West Slovakia water company, a.s. Nitra, Slovak Republic \\ ${ }^{3}$ National Agricultural and Food Centre - Research Institute of Plant Production, Piešt'any, Slovak Republic
}

PIRŠElOVÁ, B. - KUNA, R. - LUKÁČ, P. - HAVRLENTOVÁ, M.: Effect of cadmium on growth, photosynthetis pigments, iron and cadmium accumulation of faba bean (Vicia faba cv. Aštar). Agriculture (Pol'nohospodárstvo), vol. 62, 2016, no. 2, p. 72-79.

The influence of different concentrations of cadmium (Cd) ions (50 and $100 \mathrm{mg} / \mathrm{kg}$ soil) on growth, photosynthetic pigment content, Cd, and iron accumulation in faba bean (Vicia faba L. cv. Aštar) was studied under laboratory conditions. No significant changes were observed in the growth parameters of shoots (length, fresh, and dry weight). Both tested Cd doses resulted in decrease in root fresh weight by $31.7 \%$ and $28.68 \%$ and in dry weight by $32.2 \%$ and $33.33 \%$, respectively. Increased accumulation of $\mathrm{Cd}$ was observed in roots (125- and 173- fold higher than in control) and shoots (125- and 150- fold higher than in control) as a result of applied doses of Cd. Increased accumulation of iron was detected in roots (1.45- and 1.69-fold higher than in control). Decrease in the content of chlorophyll $a$ (by 25.52 and $24.83 \%$, respectively) and chlorophyll $b$ (by 6.90\%) after application of Cd 100 as well as decrease in carotenoids (by 40.39 and $38.36 \%$, respectively) was detected. Weak translocation of $\mathrm{Cd}$ from roots to shoots pointed to low phytoremediation potential of the tested bean variety in contaminated soil. However, the high tolerance of this cultivar, its relative fast growth, as well as priority of $\mathrm{Cd}$ accumulation in roots presume this plant species for phytostabilisation and revegetation of the Cd-contaminated soils.

Key words: faba bean, cadmium, tolerance, photosynthesis, oxidative stress, remediatory potential

Contamination of soils with Cadmium $(\mathrm{Cd})$ is a major threat to ecosystems. Cd is rapidly taken up by plant roots and can be loaded into the xylem for its transport to leaves. Many species accumulate toxic metals mainly in the roots (Benavides et al. 2005); according to $\mathrm{Wu}(1990)$, about $70-85 \%$ of the absorbed $\mathrm{Cd}$ remains in the roots in various plants. The differences in $\mathrm{Cd}$ accumulation capacity and localisation appear to be the major factors in determining plant tolerance to $\mathrm{Cd}$ exposure (Obata \& Umebayashi 1993). The toxic effect of Cd is re- lated to its ability to generate reactive oxygen species (ROS) resulting in unbalanced cellular redox homeostasis (Schützendübel et al. 2001). The ROS generation is indirect because $\mathrm{Cd}$ does not participate in Fenton-type reactions; therefore, it is a non-redox metal (Romero-Puertas et al. 2004). In plants, exposure to $\mathrm{Cd}$ causes inhibition of growth, activation or inhibition of enzymes, reduction of transpiration rate and water content (Benavides et al. 2005). Stomatal closure due to entry of $\mathrm{Cd}$ into the guard cells in competition to $\mathrm{Ca}^{+2}$ (Perfus-Barbeoch

RNDr. Beáta Piršelová, PhD. ( ${ }^{*}$ Corresponding author), doc. RNDr. Roman Kuna, PhD., Department of Botany and Genetics, Faculty of Natural Sciences, Constantine the Philosopher University in Nitra, Nábrežie mládeže 91, 94974 Nitra, Slovak Republic. E-mail: bpirselova@ukf.sk; rkuna@ukf.sk

RNDr. Peter Lukáč, West Slovakia water company, a.s., Nábrežie za hydrocentrálou 4, 949 01, Nitra, Slovak Republic. E-mail: rndr.peter.lukac@gmail.com

RNDr. Michaela Havrlentová, PhD., National Agricultural and Food Centre - Research Institute of Plant Production, Bratislavská cesta 122, 92168 Piešt’any, Slovak Republic. E-mail: havrlentova@vurv.sk 
et al. 2002) and reduction in stomata count per unit area are also characteristic symptoms of $\mathrm{Cd}$ stress resulting in lesser conductance to $\mathrm{CO}_{2}$ (Pietrini et al. 2010), which consequently lead to the overall inhibition of photosynthesis. In addition, $\mathrm{Cd}$ may disturb plant mineral metabolism. For example, $\mathrm{Cd}$ almost completely inhibits iron $(\mathrm{Fe})$ translocation from roots to shoots, leading to increased root $\mathrm{Fe}$ concentrations in plants (Muradoglu et al. 2015).

Many studies have attempted to clarify the mechanism of Cd toxicity in plants (Békésiová et al. 2008; Tamás et al. 2012; Balestri et al. 2014); however, relationships between growth inhibition and physiological processes under $\mathrm{Cd}$ condition are still discussed. Mainly because of the fact that its toxic effects are expressed in relation to plant species or varieties. The toxicity of $\mathrm{Cd}$ is also greatly influenced by the concentration of $\mathrm{Cd}^{2+}$ ions, their form and availability in the soil, duration of their application, as well as by other different factors of the environment ( $\mathrm{pH}$ of the soil, soil humidity, and others). There are also no univocal reports on the relationships between $\mathrm{Cd}$ stress and some physiological processes (e.g., water relations) since $\mathrm{Cd}$ can interfere in several ways on the parameters that affect these physiological processes in leaves (Barceló \& Poschenrieder 1990). Knowledge of mechanisms of plants' tolerance to heavy metals ions provides an opportunity of breeding varieties suitable for phytoremediation. Besides, metal hyper-accumulating plants, non-accumulating $\mathrm{Cd}$, and high biomass crops are also considered for phytoextraction purposes, but it has been suggested that the success of this approach might be limited by Cd-induced phytotoxicity problems (McGrath et al. 2001). Although plants belonging to family Fabaceae are sensitive to high concentrations of heavy metals (Kuboi et al. 1987), several studies indicated that plant such as Lupinus albus or Vicia faba are used in re-vegetation and phytostabilization of cadmium contaminated soils (Vazquez et al. 2006; Pichtel \& Bradway 2008).

In the presented article, the influence of different concentrations of Cd ions (50 and $100 \mathrm{mg} / \mathrm{kg}$ soil) on growth, photosynthetic pigment content, $\mathrm{Cd}$ and $\mathrm{Fe}$ accumulation in faba bean (cv. Aštar) is presented. In addition, the potential of broad bean for the phytoremediation of Cd in a contaminated soil was presented.

\section{MATERIAL AND METHODS}

\section{Plant material and growth conditions}

Seeds of beans (Vicia faba cv. Aštar) were surface-sterilized with $5 \%$ sodium hypochloride for $15 \mathrm{~min}$ and planted in pots containing mix of soil (BORA, pH 6-7, $1.0 \% \mathrm{~N} ; 0.3 \% \mathrm{P}_{2} \mathrm{O}_{5} ; 0.4 \%$ $\left.\mathrm{K}_{2} \mathrm{O}\right)$ and perlite $(4: 1)$. The plants were cultivated in a growth chamber at $20^{\circ} \mathrm{C}, 12 \mathrm{~h}$ light $/ 12 \mathrm{~h}$ dark period (illumination of $400 \mathrm{lux}$ ), and relative humidity $60-70 \%$. Pots were watered daily to $60 \%$ water-holding capacity of the soil. When the first assimilating leaves were developed, plants were supplied with distilled water (control) or two doses of $\mathrm{Cd}$ : $50(\mathrm{Cd} \mathrm{50)}$ and $100(\mathrm{Cd} \mathrm{100)}$ $\mathrm{mg} / \mathrm{kg}$ of soil, respectively. Cd was added as $\mathrm{Cd}\left(\mathrm{NO}_{3}\right)_{2} \cdot 4 \mathrm{H}_{2} \mathrm{O}$.

The test concentrations of cadmium were used due to predicted toxicity of this element to bean plants (Piršelová et al. 2015).

\section{Growth parameters}

On day 10 after application of metal solutions (BBCH 31-2 visibly extended internodes), roots were separated from the above-ground part of the plants, washed with tap water, and growth parameters (length and fresh weights) were determined. After washing, the plant samples were oven-dried at $70^{\circ} \mathrm{C}$ for $24 \mathrm{~h}$ to constant dry weight, and this parameter was also determined. Three replicates were used per treatment and eight plants from each pot were analysed (altogether 24 plants).

\section{Photosynthetic pigments determination}

For photosynthetic pigments (chlorophyll $a$ and $b$, carotenoids) analysis, fully developed trifoliate leaves were extracted with $80 \%$ acetone. Pigments contents were determined spectrophotometrically (UV-VIS spectrophotometer, Shimadzu) at the following wavelengths: 663, 646 and $470 \mathrm{~nm}$ and calculated according to Lichtenthaler and Wellburn (1983). The experiment was performed in four replicates.

\section{Determination of tolerance index}

Tolerance index (TI) was calculated as a ratio of the mean dry weight of plants grown in the presence of $\mathrm{Cd}$ and the mean dry weight of control plants expressed as percentage. 
In vivo detection of $\mathrm{H}_{2} \mathrm{O}_{2}$ in leaves

Diaminobenzidine (DAB) was used for the detection of $\mathrm{H}_{2} \mathrm{O}_{2}$ staining in leaf tissues (Thordal-Christensen et al. 1997). On day 10 after application of metal solutions, fully developed leaves (the first bifoliate - developmental stage 1 and second trifoliate - developmental stage 2) excised from Cd-treated plants (50 and $100 \mathrm{mg} \mathrm{Cd}^{2+} / \mathrm{kg}$ soil) or from untreated plants were placed in Petri dishes containing DAB solution $(1 \mathrm{mg} / \mathrm{ml})$. Plates were left in a climate chamber at $24^{\circ} \mathrm{C}$ in darkness, and DAB staining was assessed visually $12 \mathrm{~h}$ later. Leaves were bleached by immersing in boiling ethanol to visualize the brown spots characteristic of the reaction of DAB with $\mathrm{H}_{2} \mathrm{O}_{2}$.

\section{Measurements of metal content in leaves and roots}

Dried plant material (0.5 g roots and shoots) was digested in the mixture of $5 \mathrm{ml}$ water, $5 \mathrm{ml}$ of concentrated $\mathrm{HNO}_{3}$ p.a. (Merck, Darmstadt, Germany), and $1.5 \mathrm{ml}$ of $\mathrm{H}_{2} \mathrm{O}_{2}$ p.a. (Slavus, Bratislava) by using the microwave oven Mars Xpress (CEM Corporation, Matthews, USA). Decomposition temperature was $140^{\circ} \mathrm{C}$, ramp time $15 \mathrm{~min}$, and hold time $13 \mathrm{~min}$. After digestion, the solution was diluted to $25 \mathrm{ml}$ with deionised water and filtered through an acid-resistant cellulose filter (Whatman No. 42). Blank samples were prepared in a similar way. The elements $(\mathrm{Cd}$ and $\mathrm{Fe})$ were determined by electrothermal atomic absorption spectroscopy (AAS Perkin Elmer 1100B, Norwalk, Connecticut, USA).

The biological accumulation coefficient for cadmium - BAC, biological transfer coefficient - BTC and biological concentration factor - BCF were determined (Tukura et al. 2012).

$\mathrm{BAC}=$ (metal content in the above-ground part of plant $/$ metal content in soil $) \times 100$

$\mathrm{BTC}=$ (metal content in the above-ground part of plant $/$ metal content in root $) \times 100$

$\mathrm{BCF}=($ metal content in root $/$ metal content in soil $)$ $\times 100$

\section{Statistical analysis}

Data were analysed by one-way ANOVA or Kruskal-Wallis tests using XLSTAT software. The significance of differences between the concentrations of heavy metals in plant tissues was shown by using the Student's t-test, $P<0.05$ was considered as statistically significant.

\section{RESULTS AND DISCUSSION}

\section{Plant growth}

Growing in a contaminated soil, the bean plants did not show any apparent visual symptoms of intoxication by the metal. Similar conclusion was also reached by Dobroviczká et al. (2013) at cultivation of soybean (Glycine max cv. Bólyi 44, cv. Cordoba) in soil contaminated with $\mathrm{Cd}$ in concentration of $50 \mathrm{mg} / \mathrm{kg}$ soil and by Pinto et al. (2004), who exposed sorghum (Sorghum sp.) to various doses of $\mathrm{Cd}$.
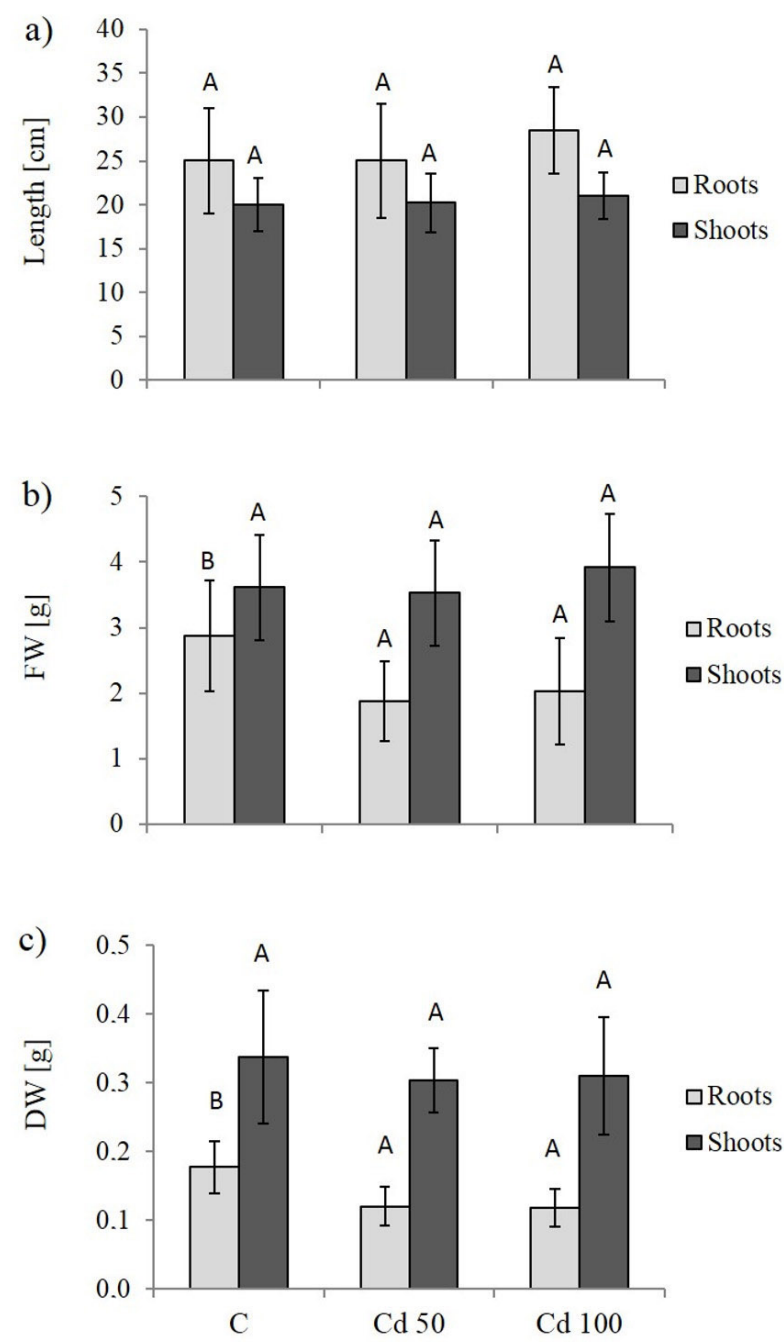

Figure 1. Effect of cadmium on length - a, fresh weight $(\mathrm{FW})-\mathrm{b}$, and dry weight (DW) - c of roots and shoots of bean plants. Data are presented as means $\pm S D, n=24$. Different letters indicate significant differences at $p<0.05$. 
Plant length, fresh and dry weight of shoots were not significantly affected by $\mathrm{Cd}$ (Figure 1); however, each of the tested doses of Cd resulted in decrease of root fresh weight by 31.70 and $28.68 \%$ and dry weight by $32.2 \%(\mathrm{TI}=67.80)$ and $33.33 \%(\mathrm{TI}=$ 66.67), respectively (Figure 1). Decrease in root biomass after exposure to $\mathrm{Cd}$ was also observed by others (Kochlar et al. 2004; Rodriguez-Serrano et al. 2009). By contrast, low doses of Cd often cause increase in the amount of fresh biomass of shoots (Pinto et al. 2004; Shah et al. 2008). In our experiment, due to doses $\mathrm{Cd} 50$ and $\mathrm{Cd} \mathrm{100,} \mathrm{the} \mathrm{length} \mathrm{of}$ shoots was also increased by $1.35 \%$ and $5.08 \%$ (Figure 1a), and fresh biomass of shoots was increased by 0.82 and $4.41 \%$, respectively (Figure $1 \mathrm{~b}$ ). Detected TI calculated on the dry mass of roots and shoots (66.67-91.99) suggests high tolerance of the given variety to $\mathrm{Cd}$. Plants with TI higher than 60 are considered as tolerant (Lux et al. 2004).

\section{Accumulation of $\mathrm{Cd}$ and $\mathrm{Fe}$ in plant tissue}

With increased concentration of the applied metal, also the increased accumulation of $\mathrm{Cd}$ in roots (125 and 173-more compared to the control) and in shoots (125 and 150-more compared to the control) of faba bean was observed (Table 1). Our results indicate that the majority of $\mathrm{Cd}$ was accumulated in the roots, which suggests a strong Cd retention during its long distance transport from roots to shoots, which might be a plant mechanism to tolerate the metal stress (Zornoza et al. 2002). Increased $\mathrm{Fe}$ accumulation was detected only in roots (1.5 and 1.69-more compared to control). In shoots, just the same content of Fe was detected in control as well as in stressed samples (Table 1). Our results correspond to the results of Luo et al. (2012), who observed increased accumulation of given metal and Fe mainly in roots influenced by $\mathrm{Cd}$ concentration. The intake of $\mathrm{Fe}$ from the soil by roots in non-graminaceous monocots and dicots is primarily regulated by the Fe transporter IRT1 (Curie \& Briat 2003). Several studies also provide strong evidence that the Fe transporter IRT1 is also primarily responsible for $\mathrm{Cd}^{2+}$ influx into root cells (Vert et al. 2002).

Although no leaves chlorosis and no changed $\mathrm{Fe}$ content in shoots were observed in our experiments, strong differences in the Fe content in roots and shoots indicate inhibition of $\mathrm{Fe}$ translocation from roots to shoots. Although the mechanism underlying Cd-induced Fe deficiency in plants has not been identified, there are several possible explanations. The root Fe-deficiency-inducible enzyme $\mathrm{Fe}(\mathrm{III})$-chelate reductase is inhibited by $\mathrm{Cd}$ (Parmar

$\mathrm{T}$ a

Cadmium $(\mathrm{Cd})$ and iron $(\mathrm{Fe})$ content in roots and shoots $[\mu \mathrm{g} / \mathrm{g}$ dry weight]

\begin{tabular}{|l|c|c|c|c|}
\hline \multirow{2}{*}{$\begin{array}{l}\text { Variant of } \\
\text { experiment }\end{array}$} & \multicolumn{2}{|c|}{ Root } & \multicolumn{2}{|c|}{ Shoot } \\
\cline { 2 - 5 } & $\mathrm{Cd}$ & $\mathrm{Fe}$ & $\mathrm{Cd}$ & $117 \pm 1.53$ \\
Control & $0.50 \pm 0.01$ & $1,035 \pm 103.00$ & $0.11 \pm 0.03$ & $108 \pm 0.71$ \\
Cd 50 & $62.26 \pm 9.60^{+}$ & $1,503 \pm 175.00^{+}$ & $13.73 \pm 3.27^{+}$ & $119 \pm 11.72$ \\
Cd 100 & $86.40 \pm 0.99^{+}$ & $1,754 \pm 104.00^{+}$ & $16.53 \pm 4.37^{+}$ & $\mathrm{Fe}$ \\
\hline
\end{tabular}

Data are presented as means $\pm \mathrm{SD} ; \mathrm{n}=3 ;{ }^{+}$indicate the level of significance at $p<0.05$

T $\quad$ a $\quad$ b 1 e e 2

Effect of soil pollution with cadmium on the biological accumulation coefficient (BAC), biological transfer coefficient (BTC), and biological concentration factor (BCF)

\begin{tabular}{|l|c|c|c|}
\hline Variant of experiment & BAC & BTC & BCF \\
\hline Cd 50 & 0.275 & 0.221 & 1.245 \\
Cd 100 & 0.165 & 0.191 & 0.864 \\
\hline
\end{tabular}


et al. 2013), suggesting that Cd may directly impair $\mathrm{Fe}$ acquisition. Also, Cd usually accumulating in roots, almost completely inhibits Fe translocation from roots to shoots, leading to increased root $\mathrm{Fe}$ concentrations in strawberry (Muradoglu et al. 2015) and mung bean (Liu et al. 2000).

As a result of the $\mathrm{Cd}$ accumulation in roots, the BAC and BTC values were very low and less than 1 (Table 2). Despite the relative high value of $\mathrm{BCF}$ at lower concentration of $\mathrm{Cd}(\mathrm{BCF}>1)$ was determined, bean are not suitable for phytoremediation of soils contaminated with $\mathrm{Cd}$ because of low BAC and BTC values. Plants exhibiting BTC (particularly $\mathrm{BCF}$ ) value less than one are unsuitable for phytoextraction (Fitz \& Wenzel 2002). However, higher BCF values (Table 2) presume this plant species for phytostabilisation and revegetation of the Cd-contaminated soils. By the influence of higher doses of $\mathrm{Cd}$, low decrease in values of $\mathrm{BAC}, \mathrm{BCF}$, and $\mathrm{BTC}$ were observed (Table 2), probably as an effect of $\mathrm{Cd}$ toxicity. Cd-dependent increase of BTC at lower concentration and decrease at higher concentration of Cd were also observed by de Maria et al. (2013) in sunflower.

\section{Pigment content and $\mathrm{H}_{2} \mathrm{O}_{2}$ accumulation in leaves}

Upon the exposure to both doses of $\mathrm{Cd}$, decreases in content of chlorophyll $a$ (by $25.52 \%$ and $24.83 \%$, respectively), chlorophyll $b$ (by $6.90 \%$ upon application of Cd 100 only) as well as carotenoids (by $40.39 \%$ and $38.36 \%$, respectively) were detected (Figure 2). These decreases were statistically significant. Reduction of the pigment contents in our study is comparable with the results of Kumar et al. (2000), who observed reduction of chlorophyll $a$ by $38.37 \%$, chlorophyll $b$ by $26.27 \%$ and carotenoids by $31.27 \%$ in broad bean leaves treated with $\mathrm{Cd}$ (120 mg/kg soil).

The results of the effect of $\mathrm{Cd}$ on the ratio of chlorophyll $a$ and $b$ diverge. The results of many authors suggest that $\mathrm{Cd}$ ions cause degradation of chlorophyll $a$ more rapidly than chlorophyll $b$, resulting in decreased $\mathrm{Chl} a / b$ ratio (Myśliwa-Kurdziel \& Strzałka 2002; Kummerová et al. 2010). On the contrary, increased $\mathrm{Chl} a / b$ ratio was observed by some authors (Azevedo et al. 2005). From the data available in the literature, it is difficult to conclude to what extent the changes in the $\mathrm{Chl} a / b$ ratio

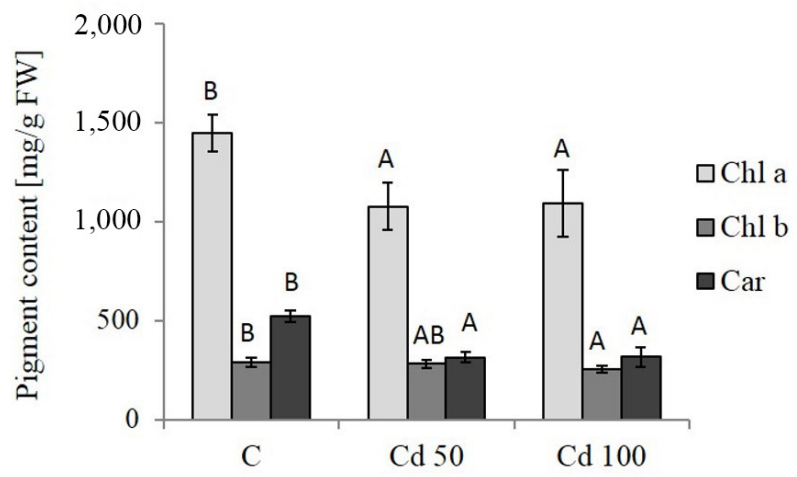

Figure 2. Chlorophyll $a$ (Chl a), chlorophyll $b$ (Chl b), and carotenoids (Car) contents in leaves affected by $\mathrm{Cd}$ (50 or $100 \mathrm{mg} / \mathrm{kg}$ soil). Data are presented as means \pm $\mathrm{SD}, \mathrm{n}=4$. FW - fresh weight. Different letters indicate significant differences at $p<0.05$.

caused by metal stress are the result of the inhibition of the enzymatic activity converting $\mathrm{Chl} a$ to $\mathrm{Chl} b$ and to what extent they derive from different rate of degradation of both chlorophyll species (Myśliwa-Kurdziel \& Strzałka 2002). Carotenoid content in plants exposed to $\mathrm{Cd}$ also does not exhibit a set pattern, and may either increase or decrease. The increase was observed in Cucumis sativus (Burzynski \& Zurek 2007) and Nicotiana tabacum (Procházková et al. 2014). Oppositely, decrease was also observed, for example, in Pisum sativum (Hattab et al. 2009).

Inhibitory effect of $\mathrm{Cd}$ on photosynthetic apparatus has previously been reported by many other authors (Kummerová et al. 2010; Wang et al. 2013), although the opposite reaction has also been observed (Bindhu \& Bera 2001). Reduction of chlorophyll content could result in enzymatic degradation of these pigments or inhibition of their biosynthesis, which could be connected with $\mathrm{Cd}$-induced deficiency of $\mathrm{Fe}$ and zinc, decrease of magnesium content or $\mathrm{Cd}$ bond to essential thiol groups in various enzymes (Parmar et al. 2013). $\mathrm{Cd}$ does not participate in Fenton-type reactions; therefore, it can only indirectly lead to oxidative stress (Romero-Puertas et al. 2004). Thus, it is much more likely that Cd-related oxidative stress is a consequence of inhibition of photosynthesis, especially in leaves. This fact is supported by the results of histochemical staining of bean leaves with $\mathrm{DAB}$ for detection of $\mathrm{H}_{2} \mathrm{O}_{2}$ (Figure 3). 
Despite the fact that on leaves no symptoms of toxicity have been observed, Cd induced a significant accumulation of $\mathrm{H}_{2} \mathrm{O}_{2}$ especially in older bean leaves treated with higher dose of $\mathrm{Cd}$ (Figure 3). While the content of $\mathrm{Cd}$ was not examined in different developmental stages of leaves, higher accumulation of $\mathrm{H}_{2} \mathrm{O}_{2}$ was observed in older leaves, which may indicate increased accumulation of $\mathrm{Cd}$ in older leaves compared with younger. The high $\mathrm{Cd}$ concentration, found mainly in roots and old leaves, suggests that plants tend to avoid toxicity in the physiologically most active portions of the plants by reducing $\mathrm{Cd}$ translocation to the epigeous portion, and by promoting the re-translocation of toxic metals from shoots to roots (de Maria et al. 2013).

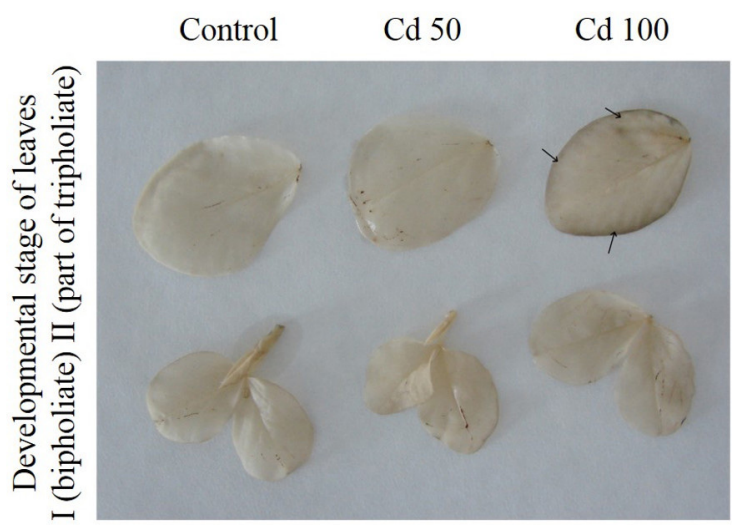

Figure 3. Histochemical detection of $\mathrm{H}_{2} \mathrm{O}_{2}$ in faba bean leaves. Arrows indicate brown deposits of $\mathrm{H}_{2} \mathrm{O}_{2}$.

\section{CONCLUSIONS}

The tested concentrations of cadmium (Cd) resulted in no visible symptoms of toxicity on faba bean cv. Aštar. Our results clearly demonstrated that photosynthetic apparatus of faba bean responded sensitively to the tested doses of $\mathrm{Cd}$ despite the high tolerance of the tested cultivar $(\mathrm{TI}>60)$; however, disruption of photosynthetic apparatus is probably not the direct effect of Fe deficiency in shoots, but by $\mathrm{Cd}$-induced changes in content of active iron (Fe) in cells (Luo et al. 2012) by emergent oxidative stress or other mechanisms. Low values of BAC and BTC show low phytoremediation potential of the given plant species in contaminated soils; however, the high tolerance of this cultivar, its relative fast growth, high biomass as well as priority of $\mathrm{Cd}$ accumulation in roots presume this plant species for phytostabilisation and revegetation of the Cd-contaminated soils. More in-depth biochemical and molecular biological analyses can contribute to revealing some further potential mechanisms of resistance of this faba bean variety to $\mathrm{Cd}$.

Acknowledgements. This work was supported by the European Community under Project no. 26220220180: Building Research Centre "AgroBioTech" and by grant No. APPV-VV-0758-11.

\section{REFERENCES}

AZEVEDO, H.G. - PINTO, G. - SANTOS, C. 2005. Cadmium effects in sunflower: membrane permeability and changes in catalase and peroxidase activity in leaves and calluses. In Journal of Plant Nutrition, vol. 28 , no. 12 , pp. 2233-2241.

BALESTRI, M. - CECCARINI, A. - FORINO, L.M.C. - ZELKO, I. - MARTINKA, M. - LUX, A. - CASTIGLIONE, M.R. 2014. Cadmium uptake, localization and stressinduced morphogenic response in the fern Pteris vittata. In Planta, vol. 239, no. 5, pp. 1055-1064. DOI 10.1007/s00425-014-2036-z

BARCELÓ, J. - POSCHENRIEDER, C. 1990. Plant wate rrelations as affected by heavy metal stress: a review. In Journal of Plant Nutrition, vol. 13, no.1, pp. 1-37.

BÉKÉSIOVÁ, B. - HRAŠKA, S. - LIBANTOVÁ, J. MORAVČÍKOVÁ, J. - MATUŠÍKOVÁ, I. 2008. Heavy-metal stress induced accumulation of chitinase isoforms in plants. In Molecular Biology Reports, vol. 35 , no. 4 , pp. $579-588$.

BENAVIDES, M.P. - GALLEGO, S.M. - TOMARO, M.L. 2005. Cadmium toxicity in plants. In Brazilian Journal of Plant Physiology, vol. 17, no. 1, pp. 21-34.

BINDHU, S.J. - BERA, A.K. 2001. Impact of cadmium toxicity on leaf area, stomatal frequency, stomatal index and pigment content in mungbean seedlings. In Journal of Environmental Biology, vol. 22, no. 4, pp. 307-309.

BURZYNSKI, M. - ZUREK, A. 2007. Effects of copper and cadmium on photosynthesis in cucumber cotyledons. In Photosynthetica, vol. 45, no. 2, pp. 239-244.

CURIE, C. - BRIAT, J.F. 2003. Iron transport and signaling in plants. In Annual Review of Plant Biology, vol. 54, pp. 183-206.

DE MARIA, S. - PUSCHENREITER, M. - RIVELLI, A.R. 2013. Cadmium accumulation and physiological response of sunflower plants to Cd during the vegetative growing cycle. In Plant Soil Environment, vol. 59, no. 6, pp. 254-261.

DOBROVICZKÁ, T. - PIRŠELOVÁ, B. - MÉSZÁROS, P. - BLEhOVÁ, A. - LIBANTOVÁ, J. - MORAVČÍKOVÁ, J. - MATUŠíKOVÁ, I. 2013. Effects of 
cadmium and arsenic ions on content of photosynthetic pigments in the leaves of Glycine $\max (\mathrm{L}$.) Merrill. In Pakistan Journal of Botany, vol. 45, no. 1, pp. 105-110.

FITZ, W.J. - WENZEL, W.W. 2002. Arsenic transformation in the soil rhizosphere-plant system, fundamental and potential application of phytoremediation. In Journal of Biotechnology, vol. 99, no. 3, pp. 259-78.

HATTAB, S. - DRIDI, B. - CHOUBA, L. - KHEDER, M.B. - BOUSETTA, H. 2009. Photosynthesis and growth responses of pea Pisum sativum L. under heavy metals stress. In Journal of Environmental Science, vol. 21, no. 11, pp.1552-1556.

KOCHLAR, S. - AHMAD, G. - KOCHLAR, V.K. 2004. Amelioration of $\mathrm{Cd}++$ toxicity by $\mathrm{Ca}++$ on germination, growth and changes in anti-oxidant and nitrogen assimilation enzymes in mungbean (Vigna mungo) seedlings. In Journal of Plant Biotechnology, vol. 6, no. 4, pp. 259-64.

KUMAR, N.M. - TOMAR, M. - BHATNAGAR, A.K. 2000. Influence of cadmium on growth and development of Vicia faba Linn. In Indian Journal of Experimental Biology, vol. 38, no. 8, pp. 819-823.

KUMMEROVÁ, M. - ZEZULKA, Š.- KRÁLOVÁ, K. MASAROVIČOVÁ, E. 2010. Effect of zinc and cadmium on physiological and production characteristics in Matricaria recutita. In Biologia Plantarum, vol. 54, no. 2, pp. 308-314.

LiCHTENTHALER, H.K. - WELlBURN, A.R. 1983 Determinations of total carotenoids and chlorophylls $\mathrm{a}$ and $\mathrm{b}$ of leaf extracts in different solvents. In Biochem Society Transactions, vol. 11, no. 5, pp. 591592.

LIU, J. - REID, R.J. - SMITH, F.A. 2000. The mechanism of cobalt toxicity in mung beans. In Physiologia Plantarum, vol. 110, no. 1, pp. 104-110.

LUO, B.F. - DU, S.T. - LU, K.X. - LIU, W.J. - LIN, X.Y. - JIN, C.W. 2012. Iron uptake system mediates nitrate-facilitated cadmium accumulation in tomato (Solanum Lycopersicum) plants. In Journal of Experimental Botany, vol. 63, no. 8. pp. 3127-36.

LUX, A. - ŠOTTNÍKOVÁ, A. - OPATRNÁ, J. - GREGER, M. 2004. Differences in structure of adventitious roots in Salix clones with contrasting characteristics of cadmium accumulation and sensitivity. In Physiologia Plantarum, vol. 120, no. 4, pp. 537-545.

MCGRATH, S.P. - ZHAO, F.J. - LOMBI, E. 2001. Plant and rhizosphere processes involved in phytoremediation of metal-contaminated soils. In Plant and Soil, vol. 232 , no. $1-2$, pp. 207-214.

MURADOGLU, F. - GUNDOGDU, M. - SEZAI, E. TARIK, E. - BALTA, F. - JAAFAR, H.Z.E. - ZIAUL-HAQ, M. 2015. Cadmium toxicity affects chlorophyll a and b content, antioxidant enzyme activities and mineral nutrient accumulation in strawberry. In Biological Research, vol. 48, no. 11. DOI:10.1186/ s40659-015-0001-3

MYŚLIWA-KURDZIEL, B. - STRZAŁKA, K. 2002. Influence of metals on biosynthesis of photosynthetic pigments. In PRASAD, M.N.V. - STRZABKA, K. Physiology and biochemistry of metal toxicity and to- lerance in plants. Dordrecht: Kluwer Academic Publishers, pp. 201-227. ISBN 1-40-200468-0

OBATA, H. - UMEBAYASHI, M. 1993. Production of SH compounds in higher plants of different tolerance to Cd. In Plant and Soil, vol. 155/156, no. 1, pp. 533536.

PARMAR, P. - KUMARI, N. - SHARMA, V. 2013. Structural and functional alterations in photosynthetic apparatus of plants under cadmium stress. In Botanical Studies, vol. 54, p. 45.

PERFUS-BARBEOCH, L. - LEONHARDT, N. VAVASEUR, A. - FORESTIER, C. 2002. Heavy metal toxicity: cadmium permeates through calcium channels and disturbs the plant water status. In The Plant Journal, vol. 32, no. 4, pp. 539-548.

PIETRINI, F. - ZACCHINI, M. - IORI, V. - PIETROSANTI, L. - FERRETTI, M. - MASSACCI, A. 2010. Spatial distribution of cadmium in leaves and on photosynthesis: examples of different strategies in willow and poplar clones. In Plant Biology, vol. 12, no. 2, pp. 355-363.

PINTO, A.P. - MOTA, A.M. - DE VARENNES, A. - PINTO, F.C. 2004. Influence of organic matter on the uptake of cadmium, zinc, copper and iron by sorghum plants. In Science of the total environment, vol. 326, no. 1-3, pp. 239-247.

PICHTEL, J. - BRADWAY, D.J. 2008. Conventional crops and organic amendments for $\mathrm{Pb}, \mathrm{Cd}$ and $\mathrm{Zn}$ treatment at a severely contaminated site. In Bioresourse Technology, vol. 99, no. 5, pp. 1242-1251.

PIRŠELOVÁ, B. - TREBICHALSKÝ, A. - KUNA, R. 2015. Sensitivity of selected crops to lead, cadmium and arsenic in early stages of ontogenesis. In Journal of Central European Agriculture, vol. 16, no. 4, pp. 476-488.

PROCHÁZKOVÁ, D. - HAISEL, D. - PAVLÍKOVÁ, D. - SZÁKOVÁ, J. - WILHELMOVÁ, N. 2014. The impact of increased soil risk elements on carotenoid contents. In Central European Journal of Biology, vol. 9, no. 7, pp. 678-685.

RODRIGUEZ-SERRANO, M. - ROMERO-PUERTAS, M.C. - PAZMINO, D.M. - TESTILLANO, P.S. - RISUENO, M.C. - DEL RIO, L.A. - SANDALIO, L.M. 2009. Cellular response of pea plants to cadmium toxicity: Cross talk between reactive oxygen species, nitric oxide, and calcium. In Plant Physiology, vol. 150, no. 1, pp. 229-243.

ROMERO-PUERTAS, M.C. - RODRÍGUEZ-SERRANO, M. - CORPAS, F.J. - GÓMEZ, M. - DEL RÍO, L.A. - SANDALIO, L.M. 2004. Cd-induced subcellular accumulation of $\mathrm{O}_{2}{ }^{-}$and $\mathrm{H}_{2} \mathrm{O}_{2}$ in pea leaves. In Plant Cell Environment, vol. 27, no. 9, pp. 1122-1134.

SCHÜTZENDÜBEL, A. - SCHWANZ, P. - TEICHMANN, T. - GROSS, K. - LANGENFELD-HEYSER, R. - GODBOLD, D.L. - POLLE, A. 2001. Cadmium-induced changes in antioxidative systems, hydrogen peroxide content, and differentiation in scots pine roots. In Plant Physiology, vol. 127, no. 3, pp. 887-898.

SHAH, F.R. - AHMAD, N. - MASOOD, K.R. - ZAHID, 
D.M. 2008. The Influence of cadmium and chromium on the biomass production of shisham (Dalbergia Sissooroxb.) seedlings. In Pakistan Journal of Botany, vol. 40, no. 4, pp. 1341-1348.

TAMÁS, L. - BOČOVÁ, B. - HUTTOVÁ, J. - LIPTÁKOVÁ, L. - MISTRÍK, I. - VALENTOVIČOVÁ, K. - ZELINOVÁ, V. 2012. Impact of the auxin signaling inhibitor p-chlorophenoxyisobutyric acid on shortterm $\mathrm{Cd}$-induced hydrogen peroxide production and growth response in barley root tip. In Journal of Plant Physiology, vol. 169, no. 14, pp. 1375-1381.

THORDAL-CHRISTENSEN, H. - ZANG, Z. - WEI, Y. - COLLINGE, D.B. 1997. Subcellular localization of $\mathrm{H}_{2} \mathrm{O}_{2}$ accumulation in papillae and hypersensitive response during the barley powdery mildew interaction. In Plant Journal, vol. 11, no. 6, pp. 1187-1194.

TUKURA, B.W. - GIMBA, C.E. - NDUKWE, I.G. KIM, B.C. 2012. Physicochemical characteristics of water and sediment in Mada River, Nasarawa State, Nigeria. In International Journal of Environment and Bioenergy, vol. 1, no. 3, pp. 170-178.

VÁZQUEZ, S. - AGHA, R. - GRANADO, A. - SARRO, M.J. - ESTEBAN, E. - PEÑALOSA, J.M. - CARPENA, R.O. 2006. Use of white lupine plant for phytostabilization of $\mathrm{Cd}$ and as polluted acid soil. In Water, Air, and Soil Pollution, vol. 177, no. 1-4, pp. 349-365.

VERT, G. - GROTZ, N. - DE' DALDE'CHAMP, F. GAYMARD, F. - GUERINOT, M.L. - BRIAT, J.F. CURIE, C. 2002. IRT1, an Arabidopsis transporter essential for iron uptake from the soil and plant growth. In The Plant Cell, vol. 14, no. 6, pp. 1223-1233.

WANG, C.X. - TAO, L. - RE, J. 2013. The response of maize seedlings to cadmium stress under hydroponic conditions. In Russian Journal of Plant Physiology, vol. 60, no. 2, pp. 295-299.

WU, L. 1990. Colonisation and establishment of plants in contaminated sites. In SHAW, A.J. (Ed) Heavy Metal Tolerance in Plants: Evolutionary Aspects. Boca Raton : CRC Press, pp. 269-284.

ZORNOZA, P. - VÁZQUEZ, S. - ESTEBAN, E. FERNÁNDEZ-PASCUAL, M. - CARPENA, R. 2002. Cadmium-stress in nodulated white lupin: strategies to avoid toxicity. In Plant Physiology and Biochemistry, vol. 40, no. 12, pp. 1003-1009.

Received: February 22, 2016 